\title{
O turismo em Foz do Iguaçu na visão dos estudantes: um estudo de percepção ambiental
}

\author{
Marta BERTIN
}

Dissertação de Mestrado: Curso de Mestrado em Geografia - UFPR

Data da defesa: 17 mar. 2003

Banca:

Salete Kozel Teixeira (orientadora)

Marcos Aurélio Tarlombani da Silveira

Oswaldo Bueno Amorin Filho

\section{RESUMO}

O problema central desta pesquisa foi analisar e compreender como o turismo tem interferido na mente dos adolescentes que vivem em Foz do Iguaçu, por meio da percepção e representação de estudantes do ensino fundamental da rede pública e particular. A possibilidade de poder descrever uma determinada realidade, a partir das observações e dos questionários aplicados, visaram a apontar soluções, a partir da percepção do turismo como prática social no município, concebido como pólo turístico de toda a região oeste paranaense. A discussão construída fundamentou-se na perspectiva humanística da geografia, respaldada no aporte teórico da fenomenologia existencial. A pesquisa busca ainda analisar como essa prática social - o turismo -, com sua capacidade de transformação dos lugares, está influenciando na relação do homem com o seu ambiente, ou seja, seu mundo vivido por meio das representações simbólicas - os mapas mentais. Diante dessas premissas, são consideradas as subjetividades, consciências in- dividuais de adolescentes, no que se refere ao enfoque da percepção ambiental e geográfica, refletindo-se nas vivências que retratam o seu mundo vivido. Na coleta das informações, o instrumento utilizado ocasionou um repensar sobre o papel dos adolescentes na sociedade atual. Os resultados desta pesquisa levaram à constatação de que os adolescentes envolvidos, que constituíram a amostra, apesar da pouca idade, possuem a consciência das implicações que o turismo, como prática social, engendra na sociedade iguaçuense. Ficou claro que é preciso incentivá-lo na escola para que haja um desencadeamento de reflexões que levem o adolescente a compreender as questões desta prática para além de suas dimensões econômicas e políticas, e sobretudo na dimensão socioespacial.

\section{Palavras-chave:}

Turismo, adolescentes, percepção ambiental. 